\title{
Anti-oxidant Effects of Hydroxytyrosol in Human Dermal Fibroblasts
}

\author{
Mi-Na Choi ${ }^{1}$, Eun-Ju Na ${ }^{2}$, In-Sook $\mathrm{An}^{3}$, Sung-Nae Lee ${ }^{4}$, Young-Sam Kim ${ }^{5 *}$ \\ ${ }^{1}$ Department of Liberal Arts, Jang-An University, Hwaseong-si, Gyeonggi-do, Korea \\ ${ }^{2}$ Department of Biological Engineering, Konkuk University, Seoul, Korea \\ ${ }^{3}$ GeneCellPharm Corporation, Seoul, Korea \\ ${ }^{4}$ Department of Cosmetology, Kyung-In Women's University, Incheon, Korea \\ ${ }^{5}$ Department of Image Industry, Graduate School of Engineering, Konkuk University, Seoul, Korea
}

\begin{abstract}
*Corresponding author: Young-Sam Kim, Department of Image Industry, Graduate School of Engineering, Konkuk University, 120 Neungdong-ro, Gwangjin-gu, Seoul 05029, Korea Tel.: +82 24503595

Email: gracehelen@konkuk.ac.kr
\end{abstract}

Received September 6, 2017

Revised November 10, 2017

Accepted November 20, 2017

Published March 30, 2018

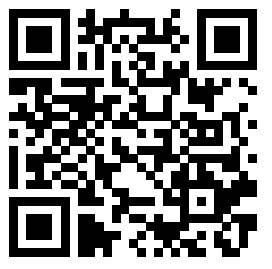

\section{Introduction}

오늘날 우리사회는 환경오염의 증가, 인구의 고령화 현상 으로 인해 인체의 세포는 그 어느 때보다 산화적 손상으로 인 한 스트레스를 많이 받게 되었으며 이러한 손상으로부터 보 호받기 위한 노력이 많은 연구 활동을 통해 이루어지고 있다 (Sies, 1997)

신체 내에서 활성산소종(reactive oxygen species, ROS) 의 생성이 증가하게 되면 지질, 단백질, DNA 파괴 및 각 종 면역물질의 활성도를 감소시키고 생체 내 세포를 손상시
키며 노화나 색소 침착과 같은 미용학적 문제를 야기시킨다 (Ciencewicki et al, 2008; Kwon et al., 2013). 따라서, 산 화적 손상을 예방하기 위한 다양한 항산화제 개발을 위한 연 구가 이루어져 왔으며, 일부 천연 항산화 물질은 세포의 산화 적 손상을 방어하며 혈관 이완작용, 항염증, 항산화, 항암효 과를 나타내는 약리 활성 성분이 풍부한 것으로 알려져 왔다 (Kikuchi et al., 2005; Ursini et al., 1986). 잘 알려져 있 는 항산화제로는 효소적 항산화제인 superoxide dismutase (SOD), catalase 및 glutathione peroxide/reductase와 비 타민 $\mathrm{E}$, 비타민 $\mathrm{C}$, 유비퀴놀, 카로티노이드, 글루타치온 및 
플라보노이드 등의 비효소적 항산화제가 주로 사용되어 왔다 (Park, 1997).

그 외에도 비효소적 항산화제로 강력한 항산화 작용을 하 는 물질로 잘 알려진 것으로는 올리브(Olive)가 있다. 올리 브는 생체 및 피부에 친화적이며 안전한 것으로 항산화 효 과 외에도 면역 체계를 강화하고 에너지를 증진시키며, 호흡 기 관련 질환, 피부 상처 감염 치료, 감기 증상 완화 등에 뛰 어난 효능을 나타내어 많은 분야에서 연구 대상이 되어 왔다 (Kitani et al., 2002). 올리브 잎은 최고의 폴리페놀 복합 체이며(Choi et al., 2008), 특히 올리브 과일과 오일에 다 량 함유되어 있는 hydroxytyrosol은 올리브 오일의 주요 페 놀 성분으로 강력한 항산화 효과를 가진 물질로 최근 기능성 식품 및 보충제의 성분으로 활발히 연구되고 있다(LopezHuertas \& Fonolla, 2017; Poudyal et al., 2017; Visioli, 2012). Hydroxytyrosol에 관해서는 마우스에서의 산화 스트 레스를 감소시키고, 혈관 내피세포에서 세포를 보호하고 신장 독성에 대해 항산화 효과가 있다는 연구 결과가 보고된바 있 다(Capasso et al., 2007; Zheng et al., 2015).

이에 본 연구에서는 hydroxytyrosol을 이용하여 세포 독 성을 알아보고, 인간 진피섬유아세포에 처리시 UVA에 의 한 산화적 손상에 대해 분자 생물학적 기전을 확인하여 hydroxytyrosol의 산화 억제 효과를 확인함으로써, 화장품의 기능성 소재로써 활용 가능성을 살펴보고자 한다.

\section{Methods}

\section{1. 세포배양}

본 연구에 사용된 인간 진피섬유아세포(Human dermal fibroblasts, HDFs)는 Sigma-Aldrich (USA)로부터 구매하 여 사용하였다. HDFs 세포의 배양은 Dulbecco's Modified Eagle Medium (DMEM; Hyclone ${ }^{\mathrm{TM}}$, USA)에 $10 \%$ fetal bovine serum (FBS; Hyclone $\left.{ }^{\mathrm{TM}}\right), 1 \%$ 페니실린/스트렙토 마이신(penicillin $100 \mathrm{IU} / \mathrm{mL}$, streptomycin $100 \mu \mathrm{g} / \mathrm{mL}$; Invitrogen $^{\mathrm{TM}}$, USA)를 함유하고 있는 배지를 사용하였고, $37^{\circ} \mathrm{C}, 5 \% \mathrm{CO}_{2}$ 가 유지되는 환경인 세포배양기 내에서 배양하
였다.

\section{2. 시료 처리}

Hydroxytyrosol (Sigma-Aldrich)은 순수정제(>90\%) 된 liquid 형태로 실험에 사용될 때는 dimethyl sulfoxide (DMSO; Sigma-Aldrich)에 적정한 농도로 용해하여 사용되 었다. 세포배양접시에 HDFs $\left(1 \times 10^{6}\right.$ cells/well)를 $24 \mathrm{~h}$ 동 안 배양 후 hydroxytyrosol을 배지에 첨가해 $6 \mathrm{~h}$ 동안 전 처 리 하였다. 세포에 UV-A lamp (UVP, USA)를 이용하여 UVA를 조사하였고, UVA 파장은 fiberoptic spectrometer system USB2000 (Ocean Optics, USA)으로 측정하였다. $\mathrm{HDFs}$ 에 UVA를 조사하기 위해 세포배양접시의 배지를 제거 한 후, $\mathrm{pH}$ 7.4의 phosphate-buffered saline (PBS)로 2회 세척하고 세포가 건조되지 않도록 $\mathrm{PBS} 1 \mathrm{~mL}$ 을 세척된 $\mathrm{HDFs}$ 에 넣어 세포배양접시의 뚜껑을 연 상태로 UVA를 조사하였 다. UVA 조사 후 $\mathrm{PBS}$ 를 제거하고 다시 새로운 배지를 첨가 하였고, 배양기에서 $24 \mathrm{~h}$ 추가 배양한 후 실험에 사용하였다.

\section{Cell viability 측정}

세포 생존율은 water-soluble tetrazolium salt-1 (WST1)의 원리를 이용하여 세포 내의 미토콘드리아 탈수소효소와 수용성인 tetrazolium salts가 반응할 때 형성되는 발색물질 인 formazan을 이용하여 세포생존율을 측정하였다. $\mathrm{HDFs}$ $\left(3 \times 10^{3}\right.$ cells/well)를 96 well plate에 접종하여 $24 \mathrm{~h}$ 배양 후, hydroxytyrosol을 농도별로 $5,10,20,30 \mu \mathrm{M}$ 로 처리 하였고, UVA 조사 후에 $24 \mathrm{~h}$ 동안 추가 배양하였다. 배양된 세포에 EZ-Cytox cell viability assay kit reagent (ItsBio, Korea) $10 \mu \mathrm{L}$ 를 첨가하여 $1 \mathrm{~h}$ 후에 microplate reader (Bio-Rad, USA)를 이용하여 $490 \mathrm{~nm}$ 에서 흡광도를 측정하 였다. 각각의 실험을 독립적으로 3 회 반복하여 수행하였으며 세포생존율 평균값과 표준편차를 도출하였다.

\section{RNA 추출과 $\mathrm{cDNA}$ 제조}

세포배양이 끝난 세포를 trizol reagent (Invitrogen ${ }^{\mathrm{TM}}$, USA)를 이용하여 용해한 후, $0.2 \mathrm{~mL}$ chloroform (Biopure, Canada)를 첨가하여 상온에서 반응하였다. $12000 \mathrm{rpm}, 4^{\circ} \mathrm{C}$

Table 1. List of primers used in this study

\begin{tabular}{lll}
\hline Gene & Forward primer & Reverse primer \\
$\beta$-actin & GGATTCCTATGTGGGCGACGA & CGCTCGGTGAGGATCTTCATG \\
SOD1 & GGGAGATGGCCCAACTACTG & CCAGTTGACATGCAACCGTT \\
$C A T$ & ATGGTCCATGCTCTCAAACC & CAGGTCATCCAATAGGAAGG \\
GPX1 & TTCCCGTGCAACCAGTTTG & GGACGTACTTGAGGGAATTCAGA \\
\hline
\end{tabular}

$\beta$-actin, actin beta; $S O D 1$, superoxide dismutase 1; $C A T$, catalase; GPX1, glutathione peroxidase. 


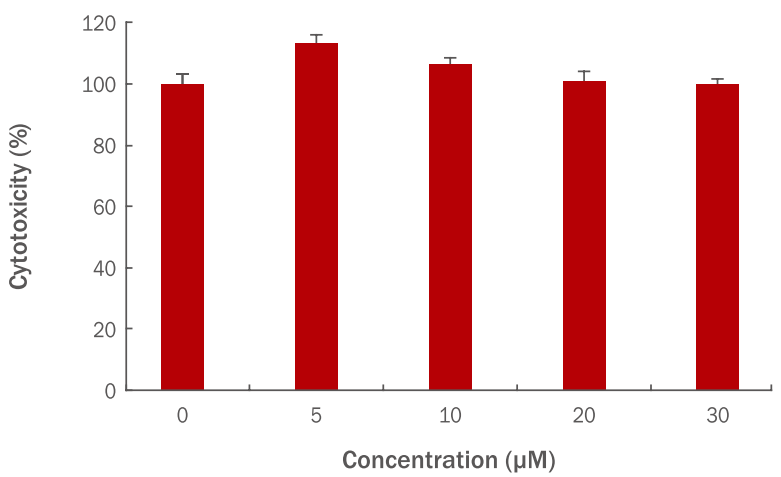

Figure 1. Cytotoxicity of hydroxytyrosol on HDFs.

HDFs ( $3 \times 10^{3}$ cells) were plated into a 96-well plate; they were then, cultured for $24 \mathrm{~h}$, and pre-treated with varying concentrations of hydroxytyrosol. After culturing for $24 \mathrm{~h}$, cellular toxicity was measured using the WST-1 assay. HDFs were treated with hydroxytyrosol at concentrations of $5,10,20$, and $30 \mu \mathrm{M}$ to confirm the cytotoxicity of hydroxytyrosol. The graph represents the mean \pm standard deviation of the relative cell viability in each sample from triplicate experiments. HDFs, human dermal fibroblasts; WST-1, water-soluble tetrazolium salt-1.

조건으로 $20 \mathrm{~min}$ 원심 분리하여 단백질이 포함된 하등액 과 mRNA가 포함된 상등액을 분리한 후, 상등액은 $0.5 \mathrm{~mL}$ isopropanol을 첨가해 $10 \mathrm{~min}$ 상온에 방치하였고, 12000 $\mathrm{rpm}, 4^{\circ} \mathrm{C}$ 조건으로 원심 분리하여 $\mathrm{RNA}$ 를 침전시키고, $75 \%$ ethanol을 이용하여 세척 후 ethanol을 제거하고 상온에 서 건조시켰다. 건조된 $\mathrm{mRNA}$ 는 $\mathrm{R}$ Nase free water를 이 용하여 녹여 실험에 사용하였고, 추출된 RNA는 Nanodrop (Maestrogen, USA)을 이용하여 260/280 nm의 ratio 1.8 이상인 순도의 RNA만을 실험에 사용하였다. 이렇게 추출 된 RNA로부터 $\mathrm{cDNA}$ 를 제작하기 위해서 $\mathrm{PCR}$ tube에 $1 \mu \mathrm{g}$ RNA, $0.5 \mathrm{ng}$ oligo dT18를 total $10 \mu \mathrm{L}$ 로 제조 후 $70^{\circ} \mathrm{C}$ 에서 $10 \mathrm{~min}$ 처리하여 RNA 변성을 유도하였고, $\mathrm{M}-\mathrm{MLV}$ reverse transcriptase (Enzynomics, Korea)을 이용하여 $37^{\circ} \mathrm{C}$ 에서 $1 \mathrm{~h}$ 반응시켜 $\mathrm{cDNA}$ 를 합성하였다.

\section{Quantitative real-time PCR}

Hydroxytyrosol에 의한 HDFs 내에서 일어나는 유전자 발현 변화를 정량적으로 분석하기 위하여 $\mathrm{qRT}-\mathrm{PCR}$ 을 이 용하였다. qRT-PCR은 PCR tube에 $0.2 \mu \mathrm{M}$ primers, 50 $\mathrm{mM} \mathrm{KCl,} 20 \mathrm{mM}$ Tris/HCl pH 8.4, $0.8 \mathrm{mM}$ dNTP, 0.5U Extaq DNA polymerase, $3 \mathrm{mM} \mathrm{MgCl}$, 1X SYBR green (Invitrogen ${ }^{\mathrm{TM}}$ )을 혼합하여 반응액을 제조하였으며, linegene $\mathrm{K}$ (BiOER, China)를 이용하여 PCR을 진행하였다. PCR의 유효성은 melting curve로 검증하였고, 각 유전자의 발현은 $\beta$-actin의 발현을 표준화하여 비교분석 하였다(Table 1).

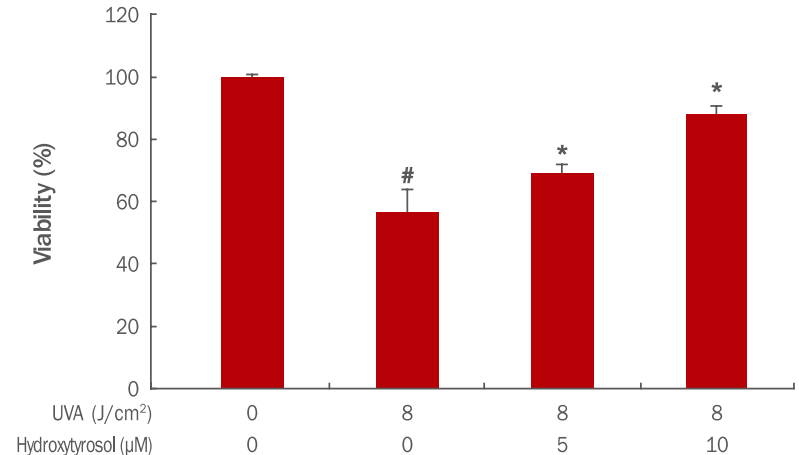

Figure 2. Protective effect of hydroxytyrosol in UVA-irradiated HDFs. HDFs $\left(3 \times 10^{3}\right.$ cells) were cultured on cell culture dishes for $24 \mathrm{~h}$ and were pre-treated with varying concentrations of hydroxytyrosol for $6 \mathrm{~h}$. Cells were washed with PBS and irradiated with UVA $\left(8 \mathrm{~J} / \mathrm{cm}^{2}\right)$. After incubation for $24 \mathrm{~h}$, cell viability was measured using the WST-1 assay. The graph represents the mean \pm standard deviation of the relative cell viability in each sample from triplicate experiments. Student's $t$-test was performed to determine statistical significance. ${ }^{\#} p<0.05$ compared with non-irradiated cells in the absence of hydroxytyrosol, and ${ }^{*} p<0.05$ compared with UVA-irradiated cells in the absence of hydroxytyrosol. UVA, ultraviolet A; HDFs, human dermal fibroblasts; PBS, phosphate-buffered saline; WST-1, water-soluble tetrazolium salt-1.

\section{6. 활성산소 측정}

세포 내의 활성산소 농도 변화를 측정하기 위해 $\mathrm{HDFs}(2$ $\times 10^{5}$ cells/well, $60 \mathrm{~mm}$ 배양 접시)을 $24 \mathrm{~h}$ 배양 한 후 hydroxytyrosol을 $5,10 \mu \mathrm{M}$ 농도별로 처리하였고, $24 \mathrm{~h}$ 추가 배양하였다. 세포 내 활성산소를 측정하기 위한 dye 인 dichlorofluorescein diacetate (DCF-DA)를 $10 \mu \mathrm{M}$ 첨가하여 $30 \mathrm{~min}$ 배양 후에 세포를 수확하여 $\mathrm{PBS}$ 를 첨 가하였고, 세포를 풀어준 다음 flow cytometry (Becton Dickinson, USA)를 사용하여 ROS 변화량을 측정하였 다. Hydroxytyrosol의 활성산소 제거 효능을 비교 - 검증 하기 위해 $\mathrm{ROS}$ 소거 능력이 뛰어난 것으로 알려져 있는 $\mathrm{N}$-acetyl-L-cysteine (NAC)을 양성 대조군으로 사용하였 고, hydroxytyrosol과 동일한 방식으로 처리 후 측정하였다.

\section{7. 통계처리}

모든 실험들은 독립적으로 3 회 반복하여 수행하였으며, 실험결과는 평균 \pm 표준 편차로 나타내었다. 실험 결과는 Student $t$-test로 검정하였으며, $p$-value 값이 0.05 이하인 경우에만 통계적으로 유의하다고 분석하였다. 


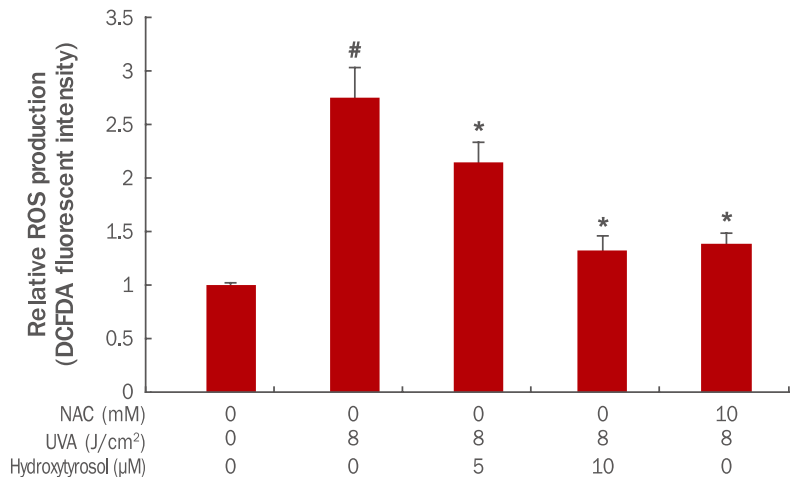

Figure 3. Effects of hydroxytyrosol on ROS scavenging in UVA-irradiated HDFs.

HDFs $\left(3 \times 10^{3}\right.$ cells) were cultured on cell culture dishes for $24 \mathrm{~h}$ and were pre-treated with varying concentrations of hydroxytyrosol for $6 \mathrm{~h}$. Cells were washed with PBS and irradiated with UVA $\left(8 \mathrm{~J} / \mathrm{cm}^{2}\right)$. After overnight incubation, DCFDA was added and ROS level changes were measured 30 min later using a flow cytometer. The graph represents the mean \pm standard deviation of the ROS level in each sample from triplicate experiments. Student's $t$-test was performed to determine statistical significance. ${ }^{*} p<0.05$ compared with non-irradiated cells in the absence of hydroxytyrosol, and ${ }^{*} p<0.05$ compared with UVA-irradiated cells in the absence of hydroxytyrosol. ROS, reactive oxygen species; NAC, N-acetyl-L-cysteine; UVA, ultraviolet A; HDFs, human dermal fibroblasts; PBS, phosphate-buffered saline; DCF-DA, 2',7'-dichlorofluorescein diacetate.

\section{Results and Discussion}

\section{Hydroxytyrosol의 세포독성}

인간 진피섬유아세포에 hydroxytyrosol을 5, 10, 20, 30 $\mu \mathrm{M}$ 농도로 각각 처리하여 hydroxytyrosol 자체의 세포독성 을 확인하였고, hydroxytyrosol $5 \mu \mathrm{M}$ 농도에서 $118 \%, 10 \mu$ $\mathrm{M}$ 에서 106\%, $20 \mu \mathrm{M}$ 에서 97\%, $30 \mu \mathrm{M}$ 에서 $100 \%$ 의 세포생 존율을 보였다. 그러므로 hydroxytyrosol $20 \mu \mathrm{M}$ 이상의 농 도에서는 세포독성이 있는 것으로 판단되어 이후 실험에서 는 hydroxytyrosol $10 \mu \mathrm{M}$ 을 최대의 사용농도로 사용하였다 (Figure 1).

\section{UVA에 대한 hydroxytyrosol의 보호효능}

UVA로 인해 손상된 인간 진피섬유아세포에서의 hydroxytyrosol의 세포보호 효능을 알아보기 위해 hydroxytyrosol을 각각 $5,10 \mu \mathrm{M}$ 의 농도로 전 처리 후 $8 \mathrm{~J} / \mathrm{cm}^{2} \mathrm{UVA}$ 를 조사하였다. 그 결과 UVA만 조 사한 대조군에서의 세포생존율이 $57 \%$ 에 비해 hydroxytyrosol 을 $5 \mu \mathrm{M}$ 전 처리한 경우 $75 \%, 10 \mu \mathrm{M}$ 에서 $88 \%$ 의 세포생존율 을 보여 hydroxytyrosol에 의해 농도 의존적으로 세포생존율 이 회복되고 있는 것을 확인하였다(Figure 2).

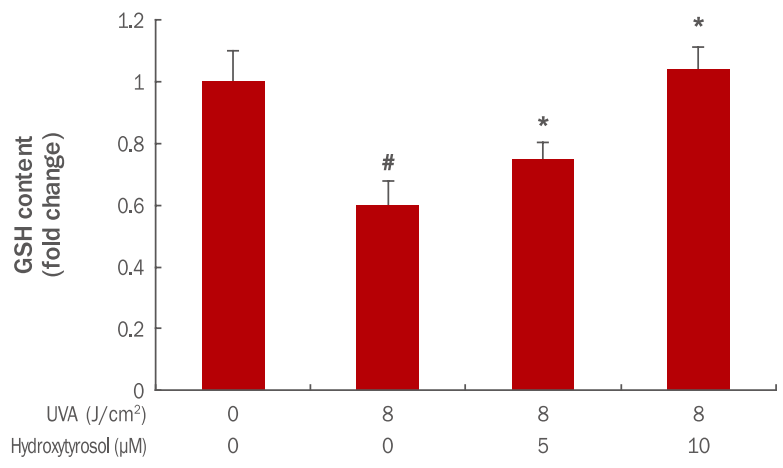

Figure 4. Effects of hydroxytyrosol on GSH activation change in UVA-irradiated HDFs.

HDFs $\left(3 \times 10^{3}\right.$ cells) were cultured on cell culture dishes for 24 $\mathrm{h}$ and were pre-treated with varying various concentrations of hydroxytyrosol for $6 \mathrm{~h}$. Cells were washed with PBS and irradiated with UVA $\left(8 \mathrm{~J} / \mathrm{cm}^{2}\right)$. After overnight incubation, cells were separated from the medium and treated with a lysis buffer. The graph represents the mean \pm standard deviation of the ROS level in each sample from triplicate experiments. Student's $t$-test was performed to determine statistical significance. ${ }^{\#} p<0.05$ compared with non-irradiated cells in the absence of hydroxytyrosol, and ${ }^{*} p<0.05$ compared with UVA- irradiated cells in the absence of hydroxytyrosol. GSH, glutathione; UVA, ultraviolet A; HDFs, human dermal fibroblasts; PBS, Phosphate buffered saline.

\section{Hydroxytyrosol의 ROS 제거 효과}

본 실험에서는 UVA로 인해 증가된 ROS가 hydroxytyrosol 에 의해 어느 정도 제거되는지에 대한 변화량을 확인하고자 하였다. 그 결과 $8 \mathrm{~J} / \mathrm{cm}^{2} \mathrm{UVA}$ 에 의해 ROS의 발현량이 1 에 서 2.75로 증가되었으나, hydroxytyrosol 각각 $5,10 \mu \mathrm{M}$ 전 처리 후 $8 \mathrm{~J} / \mathrm{cm}^{2} \mathrm{UVA}$ 조사 시 ROS의 발현량이 $2.15,1.32$ 로 감소되었다. 이 결과를 통해 hydroxytyrosol이 농도 의 존적으로 $\mathrm{ROS}$ 의 양을 감소시켜 세포 내 항산화 기능이 회복 되고 있는 것이 확인되었다. 이 실험에서는 ROS scavenger 로 알려진 N-acetyl-L-cysteine (NAC)을 양성대조군으 로 비교분석하였다. 그 결과, 양성대조군으로 사용된 $\mathrm{NAC}$ 은 $10 \mathrm{mM}$ 에서 ROS의 발현량이 1.39 로 감소하는 효과를 보 였다(Figure 3). 특히 hydroxytyrosol $10 \mu \mathrm{M}$ 처리한 경우의 $\mathrm{ROS}$ 의 양은 항산화 효과 마커로 주로 사용되는 NAC $10 \mathrm{mM}$ 처리한 양성대조군보다 그 양이 더 감소하여 hydroxytyrosol 의 ROS 제거 능력이 탁월한 것으로 사료된다(Figure 3).

\section{Hydroxyyrosol이 GSH 변화에 미치는 효과}

$\mathrm{GSH}$ 는 항산화 작용을 위한 반응을 촉매시키고 물질대사를 포함하여 세포 내 수송을 하고 세포 산화 - 환원의 균형조절 에 매우 중요한 역할을 통해 세포를 활성산소로부터 보호하는 


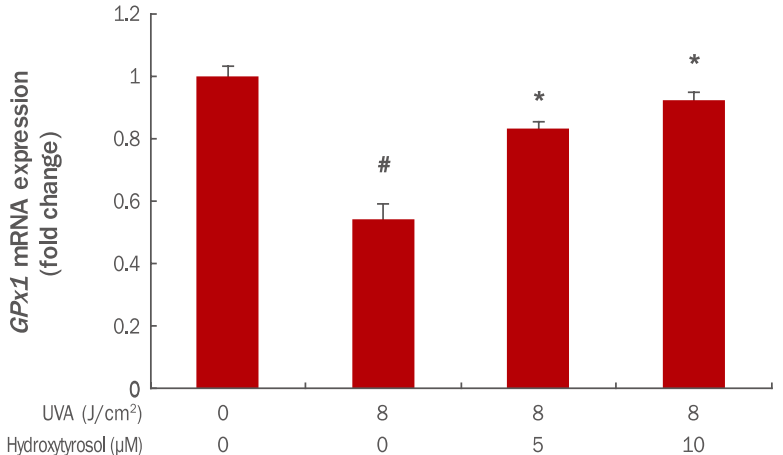

Figure 5. Effects of hydroxytyrosol on GPX1 activation change in UVA-irradiated HDFs.

HDFs were cultured for $24 \mathrm{~h}$ and pre-treated with varying concentrations of hydroxytyrosol for $6 \mathrm{~h}$. Then, the cells were irradiated with UVA for 24 h. GPX1 mRNA expression was confirmed with qRT-PCR and was found to increase with the hydroxytyrosol concentration. The graph is representative of three independent experiments with mean \pm standard deviation. The Student's $t$-test was performed to determine statistical significance. ${ }^{\#} p<0.05$ compared with non irradiated cells in the absence of hydroxytyrosol, and ${ }^{*} p<0.05$ compared with UVA-irradiated cells in the absence of hydroxytyrosol. GPX1, glutathione peroxidase 1; UVA, ultraviolet A; HDFs, human dermal fibroblasts; qRT-PCR, quantitative real time polymerase chain reaction.

역할을 한다(Lafleur et al., 1994). 따라서, hydroxytyrosol 의 세포 내 $\mathrm{H}_{2} \mathrm{O}_{2}$ 소거 정도와 $\mathrm{OH}^{-}$라디칼 생성을 억제하는 효과를 확인하고자 GSH measurement 분석법을 이용하였 다. 그 결과 $8 \mathrm{~J} / \mathrm{cm}^{2} \mathrm{UVA}$ 에 의해 $\mathrm{GSH}$ 의 양이 1 에서 0.60 로 감소되었으나, hydroxytyrosol 각각 $5,10 \mu \mathrm{M}$ 전 처리 후 8 $\mathrm{J} / \mathrm{cm}^{2} \mathrm{UVA}$ 조사 시 GSH의 양이 $0.75,1.04$ 로 증가되었다 (Figure 4). 이 결과를 통해 hydroxytyrosol이 농도 의존적 으로 항산화제인 GSH의 발현을 증가시켜 세포 내 항산화 기 능이 회복되고 있는 것으로 판단된다.

\section{Hydroxytyrosol이 GPx1 발현 변화에 미치는 효과}

세포 내 항산화 단백질 유전자인 glutathione peroxidase $(G P x 1)$ 은 $\mathrm{GSH}$ 에 의해 $\mathrm{H}_{2} \mathrm{O}_{2}$ 나 다른 organic hydroperoxide 를 환원시키는 기능을 하며 산화적 손상으로부터 세포를 보호 하는 작용을 한다(Halliwell, 1992). 본 실험에서는 UVA에 의 해 감소 된 $G P x 1 \mathrm{mRNA}$ 가 hydroxytyrosol에 의해 어느 정 도 회복되는지를 그 변화량을 확인하였다. 그 결과 $8 \mathrm{~J} / \mathrm{cm}^{2}$ $\mathrm{UVA}$ 에 의해 $G P x 1 \mathrm{mRNA}$ 의 발현이 1 에서 0.54 로 감소되었 으나, hydroxytyrosol 각각 $5,10 \mu \mathrm{M}$ 전 처리 후 $8 \mathrm{~J} / \mathrm{cm}^{2}$ $\mathrm{UVA}$ 조사 시 GPx1 mRNA 발현이 0.83, 0.92로 증가되었다 (Figure 5). 이 결과를 통해 hydroxytyrosol이 활성산소로부

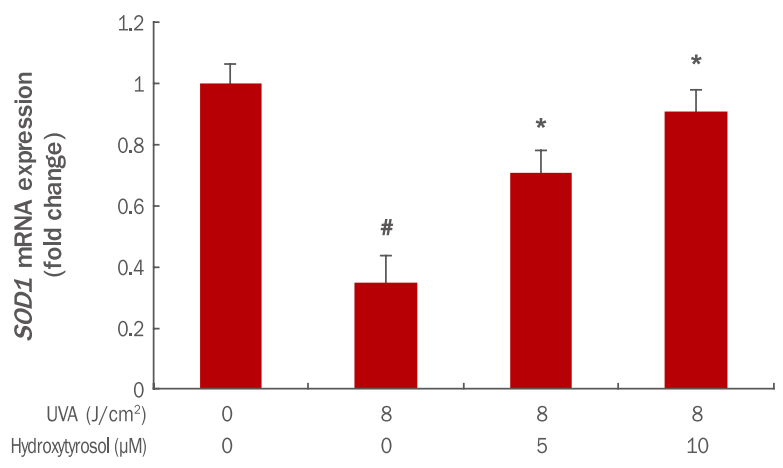

Figure 6. Effects of hydroxytyrosol on SOD1 mRNA expression in UVA-irradiated HDFs.

HDFs were cultured for $24 \mathrm{~h}$ and pre-treated with hydroxytyrosol of different concentrations for $6 \mathrm{~h}$. After UVA irradiation, cells were incubated $24 \mathrm{~h}$ in serum-added medium. SOD1 mRNA expression was confirmed using qRT-PCR and was found to increase with the hydroxytyrosol concentration. The expression of SOD1 mRNA was increased in a dose dependent manner by $5,10 \mu \mathrm{M}$ pretreatment with hydroxytyrosol. The graph represents the mean \pm standard deviation from three independent experiments. The Student's $t$-test was performed to determine statistical significance. ${ }^{\#} p<0.05$ compared with non irradiated cells in the absence of hydroxytyrosol, and ${ }^{*} p<0.05$ compared with UVA irradiated cells in the absence of hydroxytyrosol. SOD1, superoxide dismutase 1, UVA, ultraviolet A; HDFs, human dermal fibroblasts; qRT-PCR, quantitative real time polymerase chain reaction.

터 세포를 보호하는데 효과가 있는 것으로 판단된다.

\section{Hydroxytyrosoloㅇ SOD1 발현에 미치는 효과}

$\mathrm{SOD1}$ 은 주된 항산화 효소로 인체 내에서 모든 조직에 대해 산화적 스트레스를 감소시키는데 중요한 역할을 한다(Huang et al., 1999). 본 실험에서는 UVA에 의해 감소된 $S O D 1$ mRNA가 hydroxytyrosol에 의해 어느 정도 회복되는지를 확인하였다. 그 결과 $8 \mathrm{~J} / \mathrm{cm}^{2} \mathrm{UVA}$ 에 의해 $S O D 1 \mathrm{mRNA}$ 의 발현이 1 에서 0.35 로 감소되었으나, hydroxytyrosol 각각 5 , $10 \mu \mathrm{M}$ 전 처리 후 $8 \mathrm{~J} / \mathrm{cm}^{2} \mathrm{UVA}$ 조사 시 $S O D 1 \mathrm{mRNA}$ 발 현이 $0.70,0.91$ 로 증가되었다(Figure 6). 이 결과를 통해 hydroxytyrosol이 SOD1 발현을 증가시켜 활성산소를 감소 시키고 세포 및 조직을 보호하는데 효과가 있는 것으로 사료 된다.

\section{Hydroxytyrosolo이 CAT 발현에 미치는 효과}

체내 항산화 효소인 카탈라아제(catalase, CAT)는 수산화 라디칼(hydroxyl radical, $\left.\mathrm{OH}^{-}\right)$의 생성을 억제하는 기전에 서 항산화 작용을 하게 된다(Girard et al., 2006). 본 연구에 서는 산화적 스트레스를 유발시켰을 때, hydroxytyrosol 처 치로 $C A T$ 생성에 미치는 영향을 확인하고자 하였다. 그 결과 


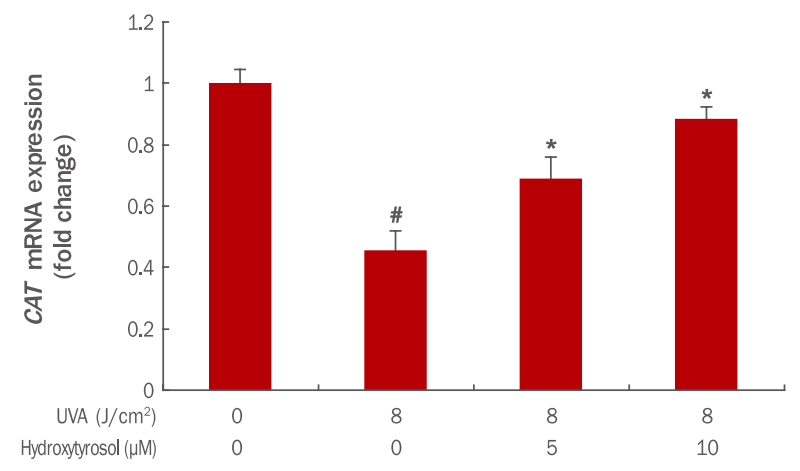

Figure 7. Effects of hydroxytyrosol on CAT mRNA expression in UVA-irradiated HDFs.

HDFs were cultured for $24 \mathrm{~h}$ and pre-treated with varying concentrations of hydroxytyrosol for $6 \mathrm{~h}$. Then, cells were irradiated with UVA and incubated $24 \mathrm{~h}$ in a medium containing serum. CAT mRNA expression was confirmed using qRT-PCR and was found to increase with the hydroxytyrosol concentration. The expression of CAT mRNA in the group treated with $5,10 \mu \mathrm{M}$ hydroxytyrosol was increased in a concentrationdependent manner. The graph represents the mean \pm standard deviation from three independent experiments. The Student's $t$-test was performed to determine statistical significance. $\# p<0.05$ compared with non irradiated cells in the absence of hydroxytyrosol, and ${ }^{*} p<0.05$ compared with UVA irradiated cells in the absence of hydroxytyrosol. CAT, catalase; UVA, ultraviolet A; HDFs, human dermal fibroblasts; qRT-PCR, quantitative real time polymerase chain reaction.

$8 \mathrm{~J} / \mathrm{cm}^{2} \mathrm{UVA}$ 에 의해 $C A T \mathrm{mRNA}$ 의 발현은 1 에서 0.46 으로 감소되었으나, hydroxytyrosol을 각각 $5,10 \mu \mathrm{M}$ 전 처리 후 $8 \mathrm{~J} / \mathrm{cm}^{2} \mathrm{UVA}$ 조사 시 $C A T \mathrm{mRNA}$ 발현은 $0.70,0.89$ 로 증 가되었다. 이 실험으로 hydroxytyrosol이 농도 의존적으로 항산화 유전자인 $C A T \mathrm{mRNA}$ 발현을 증가시켜 항산화에 효 과가 있는 것이 확인되었다(Figure 7). 즉, hydroxytyrosol 이 감소된 $C A T$ 의 회복에 관여하며 세포 내 활성산소(ROS)의 감소와 세포 노화 억제에 효과가 있는 것으로 예상된다.

\section{Conclusion}

현대인은 그 어느 때보다도 산화적 스트레스를 유발하는 환 경 속에 노출되어있다. 산화적 스트레스는 다양한 질병을 야 기하고, 신체 내외적으로 노화를 일으키는 것으로 알려져 있 어 이를 억제하기 위한 천연물 소재 개발과 연구가 식품이나 의 약학, 생명과학 분야에서 진행되어 왔다. 항산화 작용이 뛰어난 것으로 알려져 많은 분야에서 연구 대상이 되어 온 올 리브 중 과일과 오일에 주로 함유되어 있는 hydroxytyrosol 은 강력한 항산화 효과를 가진 물질로 기능성 식품 및 보충
제의 성분으로 활발히 연구되어 왔다(Lopez-Huertas \& Fonolla, 2017; Poudyal et al., 2017; Visioli, 2012). 그 러나 향장 분야에서의 hydroxytyrosol에 대한 연구는 극 히 미미하며, 인간 진피섬유아세포에서의 hydroxytyrosol 에 대한 연구는 없었던 것으로 보인다. 따라서, 본 연구에 서는 인간 진피섬유아세포에서의 산화적 스트레스에 대해 hydroxytyrosol의 항산화 효과를 확인하여 항산화 효과가 있 는 항노화 화장품 원료로서의 가능성을 알아보고자 한다.

첫째, Hydroxytyrosol을 인간 진피섬유아세포에 처리했을 때 UVA에 의한 세포 손상에 어떠한 영향을 주는지 확인하고 자 ROS 제거 및 $\mathrm{GSH}$ 의 변화, $G P x 1, \mathrm{SOD} 1, C A T$ 유전자의 발현변화를 살펴보았다.

Hydroxytyrosol의 항산화 효과를 확인한 결과 hydroxytyrosol 처리로 인해 인간 진피섬유아세포에서의 ROS 총량은 농 도 의존적으로 감소하였고(Figure 3 ), GSH의 변화값은 hydroxytyrosol 농도가 증가함에 따라 그 양이 증가하는 것 을 확인할 수 있었다(Figure 4). 특히 hydroxytyrosol $10 \mu$ $\mathrm{M}$ 처리한 경우의 ROS의 양은 NAC $10 \mathrm{mM}$ 처리한 양성대조 군보다 그 양이 더 감소하여 뛰어난 항산화 소재로서의 유효 성을 확인 할 수 있었다.

둘째, 항산화 효소인 $S O D 1$ 과 $C A T, G P x 1$ 유전자 발현 변 화에서는 hydroxytyrosol 처리로 유전자 발현이 농도 의존적 으로 증가하여(Figure 5, Figure 6, Figure 7), 항산화에 효 과가 있는 기능성 화장품으로서의 hydroxytyrosol의 활용 가 치를 확인 할 수 있었다.

이상의 결과를 통해 hydroxytyrosol은 기존에 알려진 기능 성 식품 및 보충제의 성분으로의 활용뿐만 아니라 피부세포에 서의 항산화 효과가 우수하여 피부 산화적 스트레스를 감소시 키는데 효과가 있는 기능성 화장품 소재로도 사용될 수 있을 것으로 사료된다. 또한 향후에 본 추출물이 적용된 제품을 이 용한 임상 연구가 진행된다면 화장품 및 피부 미용에 실질적 으로 응용 가능한 기능성 소재로서의 활용 가능성이 있을 것 으로 기대된다.

This work is part of the Mi-Na Choi's Ph.D. thesis at the Konkuk University, Seoul, Korea.

\section{Acknowledgements}

이 논문은 해양수산부의 재원으로 해양생명공학기술개발사 업(과제번호: 20150184) 연구개발비 지원에 의해 수행되었습 니다. 


\section{References}

Capasso G, Di Gennaro Cl, Della Ragione F, Manna C, Ciarcia R, Florio S, Perna A, Pollastro RM, Damiano S, Mazzoni O, Galletti P, Zappia V. In vivo effect of the natural antioxidant hydroxytyrosol on cyclosporine nephrotoxicity in rats. Nephrology, Dialysis, Transplantation, 23: 1186-1195, 2007.

Choi NY, Lee JH, Shin HS. Antioxidant activity and nitrite scavenging ability of olive leaf (Olea europaea L.) fractions. Korean Journal of Food Science and Technology, 40: 257-264, 2008.

Ciencewicki J, Trivedi S, Kleeberger SR. Oxidants and the pathogenesis of lung diseases. Journal of Allergy and Clinical Immunology, 122: 456-468, 2008.

Girard A, Madani S, Boukortt F, Cherkaoui-Malki M, Belleville J, Prost J. Fructose-enriched diet modifies antioxidant status and lipid metabolism in spontaneously hypertensive rats. Nutrition, 22: 758 -766. 2006.

Halliwell B. Reactive oxygen species and the central nervous system. Journal of Neurochemistry, 59: 16091623, 1992.

Huang TT, Carlson EJ, Raineri I, Gillespie AM, Kozy H, Epstein CJ. The use of transgenic and mutant mice to study oxygen free radical metabolism. Annals of the New York Academy of Sciences, 893: 95-112, 1999.

Kikuchi G, Yoshida T, Noguchi M. Heme oxygenase and heme degradation. Biochemical and Biophysical Research Communications, 338: 558-567, 2005.

Kitani K, Minami C, Yamamoto T, Kanai S, Ivy GO, Carrillo MC. Pharmacological interventions in aging and ageassociated disorders: potentials of propargylamines for human use. Annals of the New York Academy of Sciences, 959: 259-307, 2002.

Kwon SB, Lee GT, Choi SJ, Lee NK, Park HW, Lee KS, Lee
KK, Ahn KJ, An IS. The effect of glycerin, hyaluronic acid and silicone oil on the hydration, moisturization and transepidermal water loss in human skin. Asian Journal of Beauty and Cosmetology,, 11: 761-768, 2013.

Lafleur MV, Hoorweg JJ, Joenje H, Westmijze EJ, Retèl J. The ambivalent role of glutathione in the protection of DNA against singlet oxygen. Free Radical Research, 21: 9-17, 1994.

Lopez-Huertas E, Fonolla J. Hydroxytyrosol supplementation increases vitamin $\mathrm{C}$ levels in vivo. a human volunteer trial. Redox Biology, 11: 384-389, 2017.

Park SN. Skin aging and antioxidants. Journal of the Society of Cosmetic Scientists of Korea, 23: 75-132, 1997.

Poudyal H, Lemonakis N, Efentakis P, Gikas E, Halabalaki M, Andreadou I, Skaltsounis L, Brown L. Hydroxytyrosol ameliorates metabolic, cardiovascular and liver changes in a rat model of diet-induced metabolic syndrome: pharmacological and metabolism-based investigation. Pharmacological Research, 117: 32-45, 2017.

Sies H. Oxidative stress: oxidants and antioxidants. Experimental Physiology, 82: 291-295, 1997.

Ursini F, Maiorino M, Gregolin C. Phospholipid glutathione peroxidase. International Journal of Tissue Reactions, 8: 99-103, 1986.

Visioli F. Olive oil phenolics: where do we stand? Where should we go? Journal of the Science of Food and Agriculture, 92: 2017-2019, 2012.

Zheng A, Li H, Xu J, Cao K, Li H, Pu W, Yang Z, Peng Y, Long J, Liu J, et al. Hydroxytyrosol improves mitochondrial function and reduces oxidative stress in the brain of $\mathrm{db} / \mathrm{db}$ mice: role of AMP-activated protein kinase activation. British Journal of Nutrition, 1667-1676, 2015. 


\section{국문초록}

\section{인간 진피섬유아세포에서의 하이드록시티로졸의 산화억제 효능}

최미나 ${ }^{1}$, 나은주 ${ }^{2}$, 안인숙 $^{3}$, 이성내 $^{4}$, 김영삼 $^{5 *}$

${ }^{1}$ 장안대학교 교양학과, 경기도 화성시, 한국

${ }^{2}$ 건국대학교 생물공학과, 서울, 한국

3(주진셀팜, 서울, 한국

${ }^{4}$ 경인여자대학교 피부미용과, 인천, 한국

${ }^{5}$ 건국대학교 산업대학원 이미지산업학과, 서울, 한국

목적: Hydroxytyrosol은 항산화 특성을 지닌 페놀계 식물 화학 물질의 일종으로, 본 연구에서는 UVA와 hydroxytyrosol을 인간 진 피섬유아세포에 처리하여 UVA로 유도된 인간 진피섬유아세포에서의 hydroxytyrosol의 세포 내 작용 기전 연구를 통해 산화 억 제에 효과가 있는 기능성 소재로서의 가능성을 제시하고자 한다. 방법: Hydroxytyrosol의 효능 평가는 세포생존율 분석, 활성산 소 측정, qRT-PCR을 통해 검증하였다. UVA로 감소한 세포 생존율을 확인하기 위해 WST-1 assay의 원리를 이용하여 측정되었 다. Hydroxytyrosol의 항산화 효과를 입증하기 위해서 DCF-DA를 이용하여 ROS 정량분석과 GSH 변화값을 측정하였고, $G P x 1$, $S O D 1, C A T$ 유전자의 발현변화를 살펴보았다. 결과: UVA로 감소한 세포생존율은 hydroxytyrosol 농도의존적으로 증가하였다. $\mathrm{UVA}$ 로 증가된 활성산소에 대해 hydroxytyrosol 처리 시 ROS 소거와 GSH 양의 증가, GPx1, SOD1, CAT mRNA 발현량의 증가를 통해 산화 억제 효과를 확인하였다. 결론: 본 연구결과를 통하여 hydroxytyrosol이 인간 진피섬유아세포에서의 산화 억제 효과를 확인하였고, 향후 hydroxytyrosol이 적용된 제품을 통한 임상 연구가 진행된다면 항산화제, 화장품의 기능성 소재로써 응용 가능할 것으로 판단된다.

핵심어: 하이드록시티로졸, 항산화, 인간 진피섬유아세포, 자외선 $\mathrm{A}$, 화장품

이 논문은 해양수산부의 재원으로 해양생명공학기술개발사업(과제번호: 20150184) 연구개발비 지원에 의해 수행되었습니 다.

\section{참고문헌}

권승빈, 이강태, 최성진, 이나경, 박현우, 이광식, 이건국, 안규중, 안인숙. 글리세린, 히알루론산, 실리콘 오일이 피부의 보습

및 경피수분손실량에 미치는 효과. 아시안뷰티화장품학술지, 11: 761-768, 2013. 박수남. 피부노화와 항산화제. 대한화장품학회지, 23: 75-132, 1997.

최남영, 이재환, 신한승. 올리브 잎 분획물의 항산화기능과 아질산염 소거능력 평가. 한국식품과학회지, 40: 257-264, 2008. 


\title{
中文摘要
}

\section{Hydroxytyrosol对人真皮成纤维细胞的氧化抑制作用}

\author{
崔美娜 ${ }^{1}$, 羅恩朱 ${ }^{2}$, 安仁淑 ${ }^{3}$, 李星乃 ${ }^{4}$, 金永三 $^{5^{*}}$ \\ ${ }^{1}$ 长安大学教养学科, 京畿道华城市, 韩国 \\ 2建国大学生物工学科, 首尔, 韩国 \\ ${ }^{3}$ (株)健熙普 首尔, 韩国 \\ 敬仁女子大学皮肤美容科, 仁川, 韩国 \\ 5 建国大学产业大学院影像产业学科, 首尔, 韩国
}

目的: Hydroxytyrosol是一种具有抗氧化性能的酚类植物化学物质, 对UVA诱导人真皮成纤维细胞用hydroxytyrosol处 理, 通过探索hydroxytyrosol的细胞内机制, 作为抗氧化功能性材料提供可行性。方法: 利用细胞生存率测定, 活性氧 测定, qRT-PCR方法进行对hydroxytyrosol的效能评价。利用WST-1 assay原理确认由UVA减少的细胞生存率 ; 为确认 hydroxytyrosol的抗氧化效能, 利用DCF-DA进行ROS定量分析和测定GSH变化量, 以及确定GPX1、SOD1、CAT遗传因 子的表达方法。结果: 因UVA减少的细胞生存率通过hydroxytyrosol根据浓度依赖性增加; 因UVA增加的活性氧, 利用 hydroxytyrosol处理时, ROS、GSH的量减少以及GPx1, SOD1, CAT mRNA的表达量减少, 从而确认了抗氧化作用。结论: 通过研究确认了hydroxytyrosol的人真皮成纤维细胞的氧化抑制效果, 将来hydroxytyrosol产品进行临床研究, 作为抗氧 化剂和功能材料充分具有适用可行性

关键词: Hydroxytyrosol, 抗氧化, 人真皮成纤维细胞, 紫外线A, 化妆品 